\title{
Sexual arrangements in kohekohe (Dysoxylum spectabile, Meliaceae)
}

\author{
J.E. Braggins, M.F. Large and D.J. Mabberley
}

\begin{abstract}
Braggins, J.E. ${ }^{1}$, Large, M.F. ${ }^{2}$ and Mabberley, D.J. ${ }^{3}{ }^{1}$ Plant Science, School of Biological Sciences, University of Auckland, Auckland, New Zealand; ${ }^{2}$ Institute of Molecular BioSciences, Massey University, Palmerston North, New Zealand; ${ }^{3}$ National Herbarium of The Netherlands, University of Leiden, The Netherlands, and Royal Botanic Gardens, Sydney, NSW 2000, Australia) 1999. Sexual arrangements in kohekohe (Dysoxylum spectabile, Meliaceae). Telopea 8(3): 315-324. Detailed examination of floral structure in Dysoxylum spectabile (Forst. f.) Hook. f. from New Zealand reveals that individual trees are either exclusively female with flowers lacking pollen, or are male or rarely hermaphrodite with flowers producing pollen and seldom, if ever, fruit. Floral structure is described for both forms.
\end{abstract}

\section{Introduction}

Kohekohe (Dysoxylum spectabile (Forst. f.) Hook. f.) is a striking cauliflorous/ ramiflorous tree restricted to the North Island and northern South Island of New Zealand (Fig. 1), where it flowers from late autumn to winter; it is found in primary forest and persists in cleared areas forming a major component of the canopy, besides being planted in parks as an amenity tree. Its flowers, which have a creamy white staminal tube, pale green calyx and corolla, with nectar produced from a disk around the ovary (Fig. 3, 4), are visited by insects and birds which may be pollinators.

Kohekohe is the only member of the mahogany family, Meliaceae, to be found in New Zealand and is the most southerly species in a genus of some 80 species found from Sri Lanka and southern China through Malesia east to Niue (Mabberley 1995).

Mabberley (1995) records that Dysoxylum species are 'dioecious, more rarely with hermaphrodite flowers', the family including trees which are dioecious, polygamous, monoecious, or with only bisexual flowers (Mabberley 1997). Styles (1972) established that many members of the Meliaceae have functionally unisexual flowers, but that each male or female flower also has well formed though sterile rudiments of organs of the opposite gender. Pennington and Styles (1975) examined representatives from all known genera and showed that only Turraea L. and related genera have exclusively hermaphrodite individuals.

The sexual arrangements in Dysoxylum species had not been examined in the field before 1990 when DJM visited New Zealand to examine living kohekohe material and, with JEB and MFL, made some pilot studies. Since then investigations on pollen morphology in the genus (Large \& Mabberley 1994) as well as studies on D. pachyphyllum Hemsl. from Lord Howe Is. (unpublished) also indicate dioecy in the genus, although this is not always obvious.

These observations lend support to earlier reports by Styles (1972, table 1) who describes Dysoxylum fraserianum (A. Juss.) Benth. from Australia and the red bean of Australia, D. muelleri Benth., a synonym of the Malesian D. mollissimum Blume (Mabberley 1994) as dioecious. 


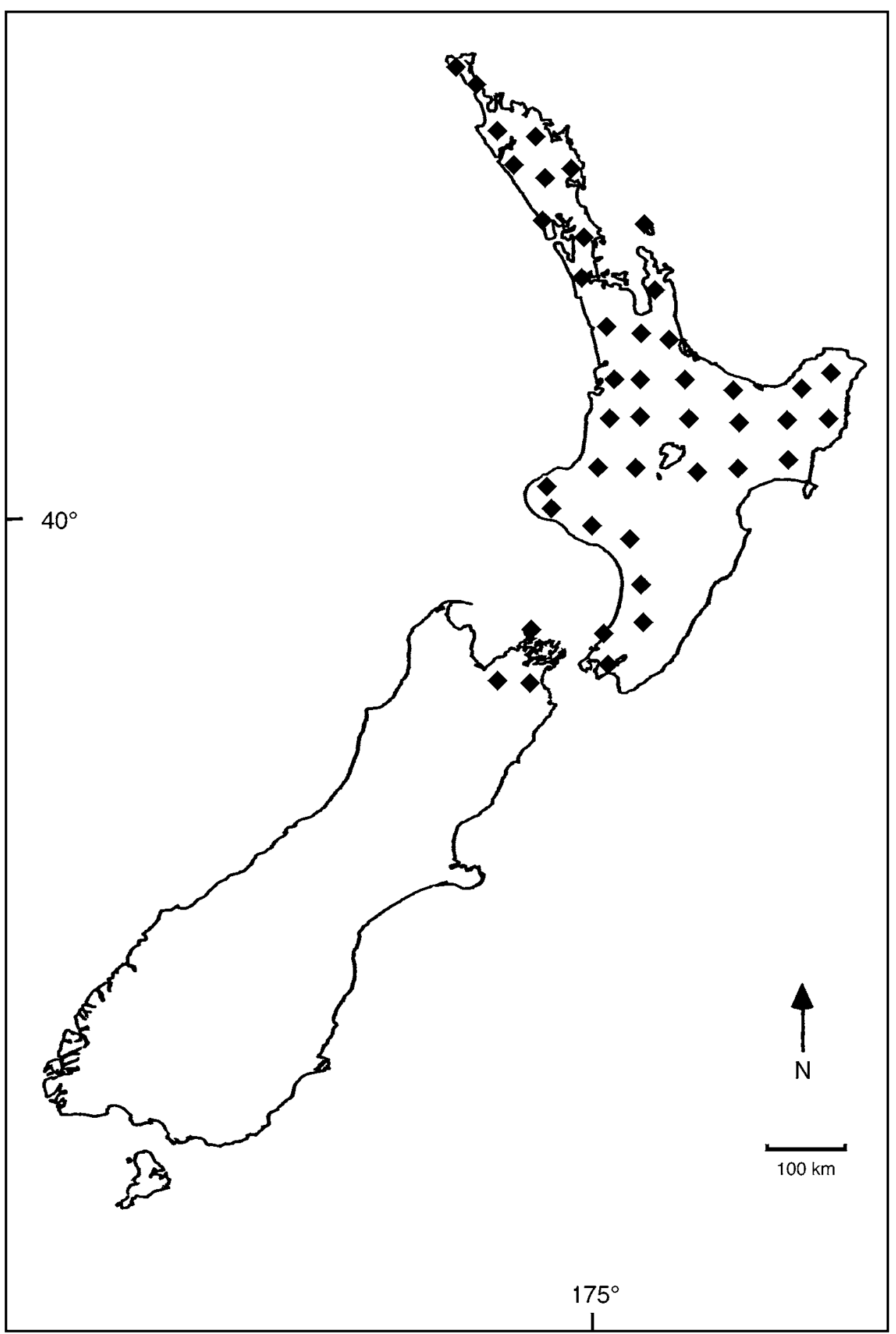

Fig. 1. Map showing the distribution of Dysoxylum spectabile in New Zealand. This information is based on herbarium material and the following sources: Allan 1961; Cheeseman 1925; Crowe 1992; Dawson 1988; Salmon 1980. 
However, despite investigations devoted to the ecology of D. spectabile, e.g. Court and Mitchell $(1988,1989)$, its dioecious nature appears not to have been previously appreciated. Kohekohe has also been the subject of many taxonomic treatments and features in most texts on New Zealand trees and other flowering plants, e.g. Allan in the New Zealand Flora (1961: 462) states that the flowers are 'perfect'. Nonetheless in several cases it is illustrated in sufficient detail that the sex of the flowers can be discerned, e.g. that in Salmon (1970: 118) being male.

Understanding the floral biology of kohekohe has been further complicated by the majority of specimens lodged in herbaria being male (a full list of material studied is available from the authors, though a representative one is presented in the Appendix).

\section{Materials and methods}

In this study carried out by JEB and MFL, fresh material of kohekohe was examined from throughout its New Zealand range with the aims of understanding and describing its functional floral biology. A list of the living subject trees is available from the authors. Herbarium vouchers are deposited in AKU.

\section{Flowers}

Flowers were collected from fruit-bearing and non fruit-bearing trees and examined for their reproductive structures. Trees were monitored throughout the flowering period (March-June) for three successive seasons (1996-1998). Calyx, corolla and staminal tube measurements were made (Fig. 2), those of the tube with a pair of electronic callipers (Mitutoyo digimatic, Mitutoyo corporation model CD-6") .

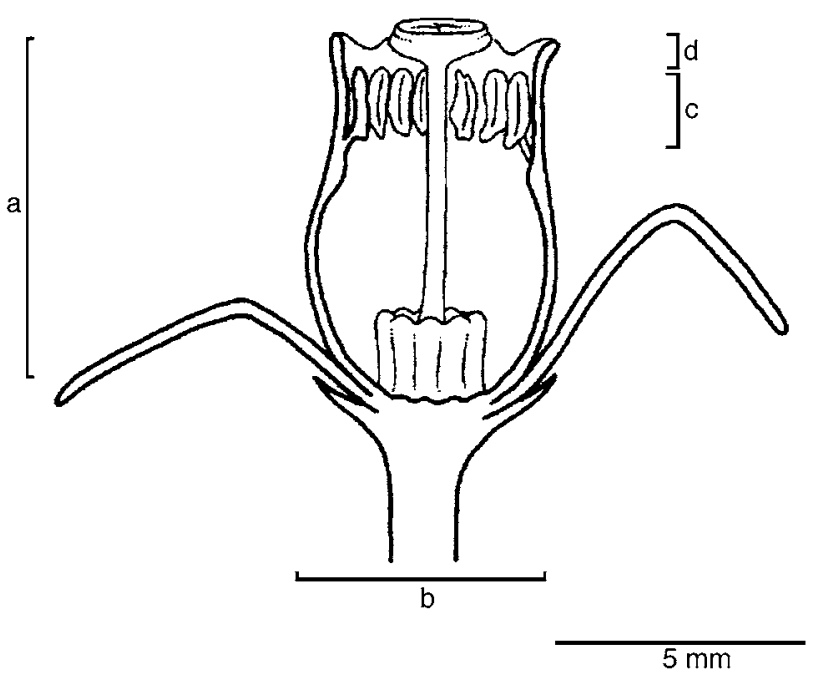

Fig. 2. Schematic LS of the flower of Dysoxylum spectabile indicating the positions of measurements given in Table 1. a, staminal tube length; $\mathbf{b}$, staminal tube width measured at the widest point; c, anther length; $d$, distance of anther tip to the upper edge of staminal tube. 
Table 1. Data summary on an individual tree basis, for female and hermaphrodite/male trees of Dysoxylum spectabile.

Sample sizes include flowers or fruits as stated sampled from three populations (2 Auckland, 1 Wellington). The sample of fruits from hermaphrodite/male trees represents all that are available from the same 3 populations. Data include mean, standard deviation and range for staminal tube length ( $F$ length); staminal tube width ( $F$ width); staminal tube length to width ratio ( $F \mathrm{~L}: W)$; number of anthers per flower ( $N^{\circ}$ of anthers); anther length; distance from the tip of the anther to the top of the staminal tube (D. top of tube); style length; style head width. The level of pollen viability; number of locules per fruit; number of seeds per locule and number of seeds per fruit are also recorded.

\begin{tabular}{|c|c|c|c|c|}
\hline Male & Mean & Sdev & Range & Sample size \\
\hline F Length mm & 7.68 & 0.74 & $5.86-9.16$ & $75 \mathrm{fl}$ \\
\hline $\mathrm{F}$ width $\mathrm{mm}$ & 4.93 & 0.61 & $3.69-6.34$ & 75 \\
\hline F L:W & 1.56 & 0.16 & $1.20-2.08$ & 75 \\
\hline $\mathrm{N}^{\circ}$ of anthers & 10.34 & 0.63 & $10-13$ & $40 \mathrm{fl}$ \\
\hline Anther length mm & 1.44 & 0.11 & $1.2-1.6$ & 40 \\
\hline D. top of tube mm & 0.9 & 0.35 & $0.3-1.4$ & 40 \\
\hline Style length mm & 8.1 & 0.62 & $6.3-9.0$ & 40 \\
\hline Style head mm & 1.4 & 0.11 & $1.0-1.6$ & 40 \\
\hline Pollen viability & $96 \%$ & 0.24 & $87-97 \%$ & 50 grains $\times 75 \mathrm{fl}$. \\
\hline No locules & - & - & $0-3$ & 6 fruits \\
\hline Seeds per locule & - & - & $0-2$ & 6 \\
\hline Seeds per fruit & - & - & $0-2$ & 6 \\
\hline \multicolumn{5}{|l|}{ Female } \\
\hline F length $\mathrm{mm}$ & 5.79 & 0.79 & $4.48-7.26$ & $65 f l$. \\
\hline F width $\mathrm{mm}$ & 5.05 & 0.49 & $4.02-6.00$ & 65 \\
\hline F L:W ratio & 1.14 & 0.16 & $0.86-1.46$ & 65 \\
\hline $\mathrm{N}^{\circ}$ of anthers & 10 & 0.34 & $10-11$ & $30 \mathrm{fl}$ \\
\hline Anther length mm & 1.27 & 0.15 & $1-1.6$ & 30 \\
\hline D. top of tube mm & 1.0 & 0.28 & $0.6-1.2$ & 30 \\
\hline Style length mm & 7.1 & 0.62 & $6.2-8.2$ & 30 \\
\hline Style head mm & 1.3 & 0.18 & $1.0-1.7$ & 30 \\
\hline Pollen viability & - & - & none & $65 \mathrm{fl}$. \\
\hline No of locules & - & - & $3-5$ & 30 fruits \\
\hline Seeds per locule & - & - & $0-3$ & 30 \\
\hline Seeds per fruit & - & - & $3-7$ & 30 \\
\hline
\end{tabular}

\section{Anthers and pollen}

Anthers were examined for the presence of pollen. Anther number per flower, length and the distance from the anther tip to the upper edge of the staminal tube are given in Table 1. Measurements were made using a stereo dissecting microscope with a calibrated eye-piece micrometer. Pollen samples from all flowers with pollen were stained with lactophenol aniline blue and separately with fluorescein diacetate (Heslop-Harrison \& Heslop-Harrison 1970) to determine levels of grain viability. Style length and style head diameter were also recorded. These data are summarised in Table 1. 


\section{Fruits}

Fruits were collected from the same trees used for the floral examination. Locule number and seed set per locule were noted. Data are summarised in Table 1.

\section{Observations}

\section{Flowers}

The shortly pedicelled flowers occur in thyrses of variable length (c. 50-530 mm long) with, in general, more per inflorescence in the male/hermaphrodite than in the female. Calyx lobes are very small (c. $3.5 \mathrm{~mm}$ ) while the corolla is longer (c. $10 \mathrm{~mm}$ ) with 4 to 5 linear petals. The staminal tube is cylindrical, fleshy and its margin crenate (Figs 3-8). There is some variation in length and width (Table 1). However, male flowers tend to have longer and narrower staminal tubes than do females. This is illustrated by the staminal tube length to width ratios (also summarised in Table 1) of 1.56 in the male and 1.14 in the female. Nectar is present in both kinds of flower and is produced in similar quantities.

\section{Anthers and pollen}

All flowers from all the trees examined in this study contained 10-13 anthers per flower. Anthers are shortly stalked and borne on thickened filaments emerging from the staminal tube (Figs 3, 4, 7, 8).

Of the trees studied, $40 \%$ to $50 \%$ consistently produced flowers with anthers which did not contain pollen. In these female flowers (Figs 4, 6, 8), anthers shrink at anthesis and are often dry in appearance. The remaining trees produced swollen anthers which open before anthesis. In these male flowers (Figs 3, 5, 7), pollen grain viability measured with fluorescene diacetate ranged from $88 \%$ to $97 \%$ in any one tree.

A detailed study of pollen of this and other species within Dysoxylum is reported by Large and Mabberley (1994: table 1, fig. 2). In D. spectabile pollen grains are spherical in equatorial view and 3-4-colpate. Colpi are narrow and short, reaching about half of the grain diameter. Exine ornamentation is slight, usually scabrate or granulate. Size (measured fresh and mounted in silicone oil): mean diameter $=35 \mu \mathrm{m} \pm 1.70$, range $29-40$, sample size $=50$.

\section{Gynoecium}

Styles are slender with disciform style heads. The upper surface of the style head is finely papillate, with papillae longer and slightly more developed in female flowers. The pollen receptive surface appears to be the margin and ventral surface which is wet and sticky in both male (Fig. 7) and female flowers (Fig. 8), but particularly so in the latter.

The fruit is an obovate pendulous capsule up to $25 \mathrm{~mm}$ long in the female with $3-5$ (usually 4) locules each with 0-2 or very rarely 3 seeds (total 4-7 per fruit) which have orange to scarlet arils containing a white sticky latex. Carpels are present in the male flowers but ovules within these are usually absent. Very rarely, fruits may be developed on 'male' trees; a total of 6 fruits only were observed throughout the three years of this study. These are smaller than the fruits produced by the females, being 1-3 locular to $20 \mathrm{~mm}$ long with 0,1 or 2 seeds (0-2 per fruit).

Locules seen in both male and female trees were often empty. The maximum number of ovules observed per locule in fruits obtained from female trees was three (or two in the fruits developed on male trees) indicating that seed number in all of the populations studied from 1996-1998, was well below potential levels. 

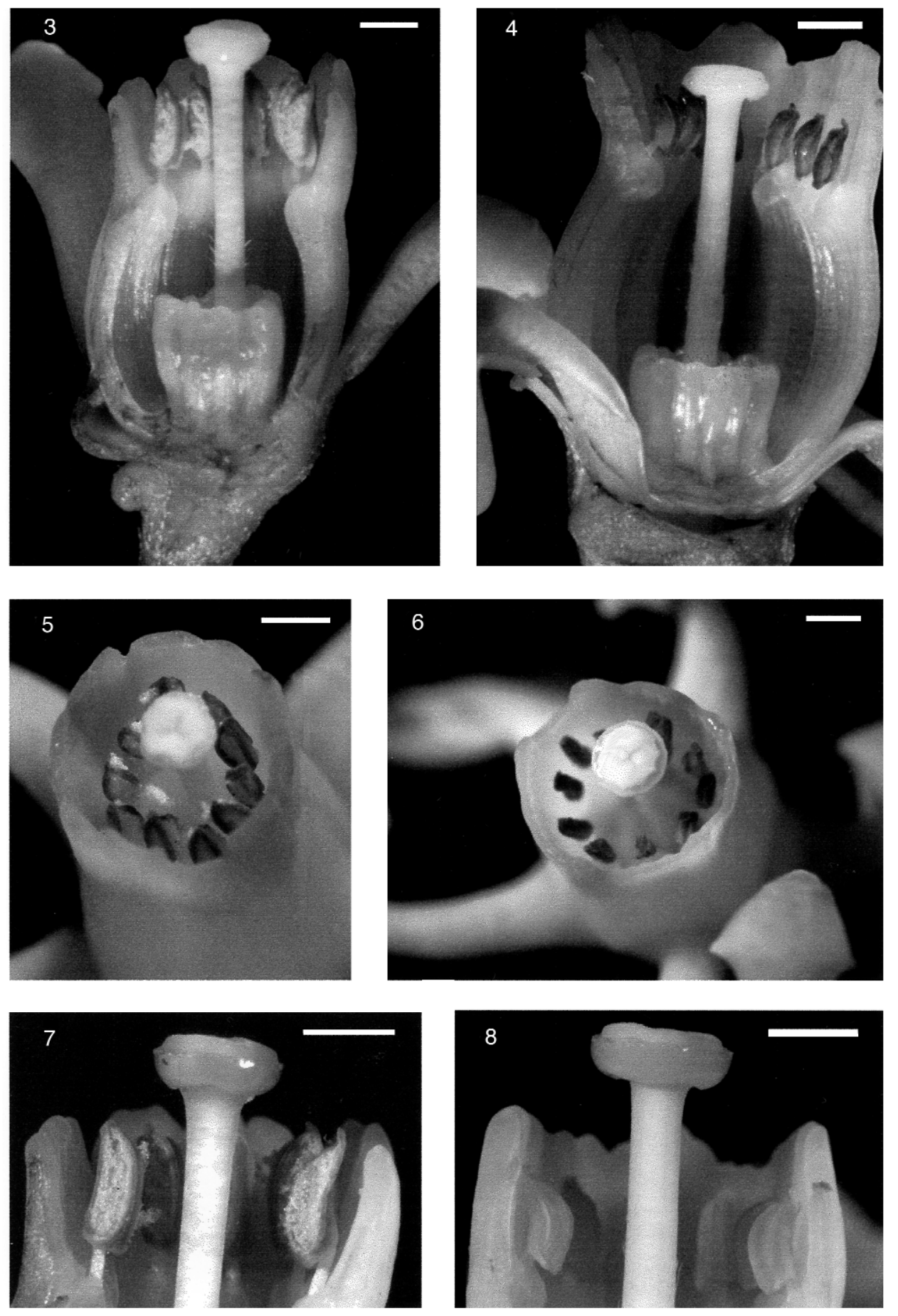


\section{Discussion}

All flowers examined in this study contained ovaries and anthers. However, there is a distinction between trees with exclusively female flowers (without pollen) and trees with male, or rarely hermaphrodite, flowers (both with pollen).

In the populations studied the ratio of male to female trees was approximately 1:1. However, male to female ratios in natural populations of kohekohe are difficult to assess. Plants often only bear flowers on upper branches. When growing in crowded stands, these branches may become intertwined complicating determination of the source of flowering material. Assessment of the proportion of females by examining fruit set may also be misleading and underestimate natural levels. This is complicated by the rare setting of fruits by 'male' trees and the fluctuating yearly production of fruits by female trees. In any year an individual may have few flowers and thus set few fruits.

Flowering varies from year to year, with heavy flowering seasons usually followed by lighter ones. Male trees may be especially floriferous carrying more inflorescences and more flowers per inflorescence than female trees. This probably explains the bias in herbarium material towards male specimens. Individual flowers from female trees have a shorter and wider staminal tube (see Table 1) than do flowers on male trees. This difference is more pronounced in populations of kohekohe in the southern parts of its range.

The sexual arrangement exhibited by kohekohe can be described as a modified form of androecy. Although it may be easy to recognise female flowers (and consequently female trees) by the absence of pollen and shorter staminal tube, it is not as easy to understand the true functional and effective gender of the few trees with flowers which produce pollen and occasional fruits. Lloyd (e.g. 1974 a \& b, 1975, 1976, 1980) argues that a continuum from hermaphroditism through gynodioecy to dioecy may exist, and points out that sexual arrangements are not always obvious from morphology.

Although this is the first time any member of the genus, or indeed of the family, has been examined for sexual arrangements for so long a period over such a wide range, it is sobering to consider that even as well known a tree as the red maple (Acer rubrum L.) in North America had many surprises (see Primack \& McCall 1986). It is clear that further detailed work is required to verify the complete reproductive story for kohekohe and the genus Dysoxylum in general. When dioecy has only lately been recorded for the first time in the widespread Labiatae-Viticoideae in no less than the common Old World tropical Premna serratifolia L. (Mabberley 1992) it is also clear that the phenomenon may be much more widespread than even Bawa et al. (1985) have indicated.

Fig. 3. (Opposite page) LS of male flower of Dysoxylum spectabile with part of the calyx, corolla and anther tube removed so that the form and position of the anthers, gynoecium and nectar-producing disk can be seen. Scale bar $=1 \mathrm{~mm}$ Fig. 4. LS of female flower of Dysoxylum spectabile with part of the calyx, corolla and anther tube removed and showing the staminal tube with dry pollen-less anthers. The nectar-producing disk is visible surrounding the ovary at the base of the style. Scale bar $=1 \mathrm{~mm}$ Fig. 5. Male flower of Dysoxylum spectabile showing swollen anthers and pollen. Dehiscence occurs in late bud stage only. In very young buds the anthers are closed. Scale bar $=1 \mathrm{~mm}$ Fig. 6. Female flower of Dysoxylum spectabile showing dried, shrunken, indehiscent anthers. Scale bar $=1 \mathrm{~mm}$ Fig. 7. Enlargement of stigma and anthers from male flower of Dysoxylum spectabile. Anthers are large and releasing pollen. The wet pollen receptive surface on the margin and ventral surface of the style head is visible. Scale bar $=1 \mathrm{~mm}$ Fig. 8. Enlargement of stigma and anthers from female flower of Dysoxylum spectabile. Anthers are shrunken and without pollen. The wet pollen receptive surface on the margin and ventral surface of the style head is visible. Scale bar $=1 \mathrm{~mm}$ 


\section{Acknowledgments}

We wish to acknowledge the assistance of Karen Sheath with measurements and preparation of the figures, Astrid Diksgraff for the provision of samples and discussion, and Sandra Anderson for the loan of equipment and sharing her ideas.

\section{References}

Allan, H.H. (1961) Flora of New Zealand, vol. 1. (Government Printer: Wellington).

Bawa, K.S., Perry D.R. \& Beach, J.H. (1985) Reproductive biology of tropical lowland rainforest trees I. Sexual systems and incompatibility mechanisms. Amer. J. Bot. 72: 331-345.

Cheeseman, T.F. (1925) Manual of the New Zealand Flora, revised edition. (Government Printer: Wellington).

Court, A.J. \& Mitchell, N.D. (1988) The germination ecology of Dysoxylum spectabile (Meliaceae). New Zealand J. Bot. 26: 1-6.

Court, A.J. \& Mitchell, N.D. (1989) The growth responses of Dysoxylum spectabile (Meliaceae) to a shaded environment. New Zealand J. Bot. 27: 353-357.

Crowe, A. (1992) Which Native Tree? (Viking Pacific: Auckland).

Dawson, J. (1988) Forest Vines to Snow Tussocks. (Victoria University Press: Wellington).

Heslop-Harrison, J. \& Heslop-Harrison, Y. (1970) Evaluation of pollen viability by enzymatically induced fluorescence: intracellular hydrolysis of fluorescein diacetate. Stain Technol. 45:3 $115-120$.

Large, M.F. \& Mabberley, D.J. (1994) The pollen of Dysoxylum (Meliaceae): the demise of Pseudocarapa. J. Linn. Soc., Bot. 116: 1-12.

Lloyd, D.G. (1974a) Theoretical sex ratios of dioecious and gynodioecious angiosperms. Heredity 31: 11-34

Lloyd, D.G. (1974b) The genetic contribution of individual males and females in dioecious and gynodioecious angiosperms. Heredity 32: 45-51.

Lloyd, D.G. (1975) The maintenance of gynodioecy and androdioecy in angiosperms. Genetica 45: 325-339.

Lloyd, D.G. (1976) The transmission of genes via pollen and ovules in gynodioecious angiosperms. Theor. Populat. Biol. 9: 299-316.

Lloyd, D.G. (1980) Benefits and handicaps of sexual reproduction. Evol. Biol. 13: 69-111.

Mabberley, D.J. (1992). Architecture of Verbenaceae of Madang Province, with preliminary notes on their reproductive biology. Sci. New Guinea 19: 37-45.

Mabberley, D.J. (1994) New Species of Dysoxylum (Meliaceae). Blumea 38: 303-312.

Mabberley, D.J. (1995) Dysoxylum. Flora Malesiana I, 12 (1): 61-136.

Mabberley, D.J. (1997) The Plant-Book: A portable dictionary of vascular plants, ed. 2. (Cambridge University Press: Cambridge).

Pennington, T.D. \& Styles, B.T. (1975) Generic conspectus of the Meliaceae. Blumea 22: 419-540.

Primack, R.B. \& McCall, C. (1986) Gender variation in a Red Maple population (Acer rubrum; Aceraceae): A seven year study of a polygamodioecious species. Amer. J. Bot. 73: 1239-1248.

Salmon, J.T. (1970) New Zealand Flowers and Plants in Colour. (Reed: Wellington).

Salmon, J.T. (1980) The Native Trees of New Zealand. (Reed Methuen: Auckland).

Styles, B.T. (1972) The flower biology of the Meliaceae and its bearing on tree breeding. Silvae Genet. 21: 149-204. 


\section{Appendix Representative list of the herbarium material of Dysoxylum spectabile examined in this study.}

The specimens listed are of flowering material only (a complete list is available from the authors): AK (Auckland Institute and Museum, NZ); AKU (University of Auckland, NZ); WELT (National Museum of New Zealand); WELTU (Victoria University of Wellington, NZ). Collector, date of collection, and location are included where available.

\begin{tabular}{|c|c|c|c|}
\hline $\begin{array}{l}\text { Herbarium No. } \\
\text { MALE }\end{array}$ & Collector & Date collected & Location \\
\hline AK 27565 & K Wood & 13 Aug 1960 & Halls Res, Huia \\
\hline AK 144188 & P Hynes & 3 July 1951 & Waikawhai Park \\
\hline AK 132273 & DL Knowlton & 12 Sept 1942 & Smiths Bush \\
\hline AK 11364 & Herb. Kirk & - & Auckland \\
\hline AK 50701 & HE Powell & 6 June 1948 & Purewa Bush Ak \\
\hline AK 31837 & JS Edwards & June 1953 & Waiheke Is \\
\hline AK 213026 & JL Barton & 5 June 1960 & Piccadilly Rd Kaikohe \\
\hline AK 213027 & JL Barton & 11 May 1960 & Waimatenui State Forest Tutamoe \\
\hline AK 126815 & RC Cooper & 8 June 1966 & Waipu Gorge Whangarei \\
\hline AK 150638 & AE Wright & 25 May 1979 & Fanal Is Mokohinau Gp \\
\hline AK 127541 & F Shakespear & 1900-1902 & Little Barrier Is \\
\hline AK 109119 & ED Smith & $1892-1910$ & Little Barrier Is \\
\hline AK 118088 & ED Smith & $1892-1910$ & Little Barrier Is \\
\hline AK 104240 & - & 7 July 1909 & Te Aroha \\
\hline AK 104234 & J Adams & - & Thames \\
\hline AK 123109 & RC Cooper & 11 May 1965 & Katikati Tuahu Head \\
\hline AK 126839 & RC Cooper & 3 July 1966 & Makau Pa Waitomo \\
\hline AK 143110 & AE Wright & 27 May 1977 & Abel Head Farewell Spit \\
\hline AK 142240 & AE Orchard & 16 July 1977 & M'more Hosp Otahuhu \\
\hline AK 229853 & TF Cheeseman & June 1883 & Orakei \\
\hline AK 5051 & TF Cheeseman & June 1883 & Orakei \\
\hline AK 229855 & TF Cheeseman & June 1883 & Orakei \\
\hline AKU 011380 & EK Cameron & 3 June 1974 & Exhib Dr Titirangi \\
\hline AKU 011275 & Ball & May 1885 & Titirangi \\
\hline AKU 018973 & JM Moss & 27 April 1985 & Whangaripo Valley \\
\hline WELT $63821 a$ & Banks \& Solander & 1833 [sic] & New Zealand \\
\hline WELT 29794 & D Petrie & 1904 & Mt Eden Auckland \\
\hline WELT 29802 & D Petrie & 1920 & Mt Eden Auckland \\
\hline WELT 29803 & D Petrie & 1908 & Waiwera Auckland \\
\hline WELT 29804 & D Petrie & 1909 & Waiwera Auckland \\
\hline WELT 29800 & T Kirk & - & Auckland \\
\hline WELT 29801 & T Kirk & - & Auckland \\
\hline WELT 29796 & T Kirk & - & Auckland \\
\hline WELT 58016a & J Buchanan & - & Kawau Auckland \\
\hline WELT 77425 & JA McMahon & 1926 & Double Bay \\
\hline WELT 39404 & WRB Oliver & - & Waikanae Wellington \\
\hline
\end{tabular}




$\begin{array}{llll}\text { Herbarium No. } & \text { Collector } & \text { Date collected } & \text { Location } \\ \text { ELT } 62762 & \text { B Ending } & 1972 & \text { Waikanae Wellington } \\ \text { WELTU } 18267 & \text { J McClean } & 1962 & \text { Maungaroa } \\ \text { WELTU } 3673 & \text { GM Auther } & 1948 & \text { New Plymouth } \\ \text { FEMALE } & & & \\ \text { AK } 215526 & \text { AE Esler et al. } & \text { 29 June 1978 } & \text { Cornwall Park } \\ \text { AK } 208597 & \text { AJ Dakin } & \text { 11 June 1973 } & \text { Kirks Bush Papakura } \\ \text { AKU } 018978 & \text { AM McCarrison } & 9 \text { May } 1985 & \text { Tram Valley Rd Swanson } \\ \text { AKU 007870 } & \text { AG Simpson } & \text { Aug 1961 } & \text { Bot. Garden Wellington } \\ \text { WELT } 63821 \mathrm{~b} & \text { Banks \& Solander } & & \text { New Zealand } \\ \text { WELTU 3672 } & \text { JA Hay } & 1949 & \text { Wellington } \\ \text { WELTU 3676 } & \text { DA Franklin } & 1957 & \text { Waikanae Wellington }\end{array}$

